\title{
Recenzja: The Nature of Human Creativity, edited by Robert J. Sternberg and James C. Kaufman, Cambridge University Press, Cambridge 2018
}

\begin{abstract}
Abstrakt
Recenzja najnowszej pracy zbiorowej pod redakcją R. J. Sternberga i J. C. Kaufmana, w której zaproszeni autorzy relacjonują własną drogę badawczą i oceniają stan rozwoju nauk o twórczości.
\end{abstract}

\section{Review: The Nature of Human Creativity, edited by Robert J. Sternberg and James C. Kaufman, Cambridge University Press, Cambridge 2018}

\begin{abstract}
A review of the latest collective work edited by R. J. Sternberg and J. C. Kaufman, in which the invited authors report on their own research path and assess the state of development of the creativity-related sciences (creatology).
\end{abstract}

Pomysł na jeszcze jedną pracę zbiorową o twórczości i kreatywności wydaje się być bardzo... twórczy. Oto bowiem dwóch bardzo zasłużonych dla rozwoju współczesnej kreatologii badaczy z uczelni amerykańskich, Robert J. Sternberg i James C. Kaufman, zaprosiło do wspólnej publikacji dwudziestu czterech autorów, reprezentujących różne nurty kreatologii, którzy byli najczęściej cytowani w czterech uważanych za najbardziej znaczące dla tej dziedziny wiedzy prac naukowych w ostatnich 20 latach: Creativity 101 (red. J. C. Kaufman 2016), The Cambridge Handbook of Creativity (red. Kaufman, Sternberg, 2010), Explaining Creativity (Sawyer 2012) i Creativity. Theories and Themes... (Runco 2014). Wszyscy ci top-cited

\footnotetext{
* Uniwersytet Łódzki, Wydział Nauk o Wychowaniu, Katedra Edukacji Artystycznej i Pedagogiki Twórczości.
} 
individuals zgodzili się napisać rozdziały do recenzowanej pracy, godząc się z podstawową zasadą, zaproponowaną przez redaktorów tomu, a mianowicie, że w swoich tekstach odpowiedzą na dziesięć najważniejszych ich zdaniem pytań nauk o kreatywności:

1. Czym jest twórczość/kreatywność?

2. Jakie jest jej najlepsze rozumienie?

3. Jak najlepiej mierzyć twórczość?

4. W jaki sposób najlepiej badać twórczość?

5. Jakie są najciekawsze wyniki własnych badań empirycznych?

6. Jakie są źródła indywidualnych i grupowych różnic w kreatywności?

7. Jak najlepiej rozwijać kreatywność?

8. Jakie są najważniejsze pytania pod adresem przyszłych badań nad twórczością?

9. Jaka jest, a jaka powinna być rola kreatywności w społeczeństwie?

10. Co chciałbyś, żeby było Twoim trwałym wkładem w dziedzinie badań nad kreatywnością?

Trzeba przyznać, że są to pytania poważne i trudne, nawiązują bowiem zarówno do ocen własnego dorobku badawczego zaproszonych i wybitnych gości, jak i do oceny stanu naukowego reprezentowanej przez nich dziedziny nauki. Wśród autorów znaleźli się tak znani i wybitni badacze, jak: Teresa Amabile, współtwórczyni społecznej psychologii twórczości i zarządzania, John Baer (psychologia i pedagogika twórczości), Ronald Beghetto (pedagogika i psychologia twórczości), Arthur Cropley (psychologia zarządzania i pedagogika twórczości), czołowy badacz osobowości twórczej Gregory Feist, twórca teorii inteligencji wielorakich Howard Gardner, autor najpopularniejszej koncepcji zdolności i wzbogaconego nauczania dzieci zdolnych, Joseph Renzulli, popularyzatorka teorii twórczości codziennej, Ruth Richards, czołowy kreatolog ogólny, Mark Runco i autor jednego z najlepszych podręczników ogólnych kreatologii - Keith Sawyer, wybitny badacz geniuszu, Dean Simonton, dwaj znani psychologowie twórczości i psychologii poznawczej - Thomas Ward i Robert Weisberg oraz kilku innych badaczy. Wstępem dzieło to opatrzył Mihaly Csiksznetmihalyi, słynny autor teorii flow oraz systemowej teorii twórczości, współtwórca psychologii pozytywnej.

Redaktorzy tomu wyraźnie zaznaczają: „Książka nie jest podręcznikiem, autorzy nie byli proszeni o reprezentowanie całego kierunku badań, raczej poproszono ich o skupienie się na własnej pracy i jej związku z pracą innych" (s. XX). Głównym celem tej książki, jak piszą, jest dostarczenie szerokiego przeglądu podejść czołowych naukowców w tej dziedzinie, aby lepiej zrozumieć naturę kreatywności, jej pomiar, badanie, rozwój i znaczenie dla społeczeństwa. Jest to ważne z tego względu, że twórczość i kreatywność są bardzo różnorodnie rozumiane przez badaczy reprezentujących różne pola naukowe i warto zapoznać się z tymi rozumieniami, 
ponadto warto ugruntować naukowe, oparte na badaniach empirycznych, wnioski o tym zjawisku w sytuacji, gdy wiele mitologicznych i przekłamanych stereotypów ciągle krąży po mediach i popularnych poradnikach.

Dla badaczy twórczości, młodszych i starszych, najciekawsze w moim przekonaniu wydają się być te wątki obecne w niemal wszystkich rozdziałach, które mają charakter autobiograficzny i ukazują często długą, skomplikowaną, pełną epifanii i transgresji, drogę dochodzenia znanych autorów do określonych teorii, wniosków i metod badań twórczości, uważanych dzisiaj przez nich za najbardziej trafne i owocne. Czytelnik może prześledzić karierę naukową, wahania i dylematy, rozwiązania i olśnienia Teresy Amabile z Uniwersytetu Harvarda, autorki bardzo znanej metody badań dokonań twórczych - Consensual Assessment Technique (CAT) i teorii motywacji wewnętrznej w twórczości (Creativity and the Labor of Love). Dowie się, z jakimi mitami o kreatywności walczył słynny australijski psycholog pracujący w Niemczech, Arthur Cropley (Bringing Creativity down to Earth: A Long Lost?), a jak do koncepcji twórczości grupowej i znaczenia improwizacji w twórczości artystycznej dochodził Keith Sawyer (An Interdisciplinary Study of Group Creatvity) i dlaczego po wielu latach starannych badań typu case study Robert Weisberg uważa, że natura procesów twórczych w różnych dziedzinach, od sztuki po naukę, jest podobna (Reflections of a Personal Journey Stydying the Psychology of Creativity). Może też mieć okazję zapoznania się z nowymi pojęciami i teoriami oraz ich eksplikacją, które mają być według autorów lepsze od istniejących dotychczas, na przykład z teorią twórczości autentycznej (authentic creativity - Mark Runco, Authentic Creativity: Mechanism, Definitions and Empirical Efforts) czy najciekawszą w moim przekonaniu w całym tomie, nową koncepcją tytana pracy naukowej Roberta Sternberga - triangulacyjną teorią twórczości (The Triangle of Creativity). Teoria ta mówi, że istotą twórczości jest przeciwstawienie się czy też wyzwanie (ang. defying) na trzech poziomach: przeciwstawienie się społeczności (defying the crowd), przeciwstawienie się samemu sobie (defying oneself) i przeciwstawienie się Duchowi Czasu (defying the Zeitgeist). Kombinacja tych czynników prowadzi autora do wyspecyfikowania ośmiu typów twórczości, od „rzadkiej kreatywności”, poprzez „kreatywność wyizolowaną” aż do „twórczości doskonałej”.

Książka kończy się podsumowaniem, w którym - bazując na odpowiedziach zaproszonych autorów - redaktorzy tomu próbują sformułować konkluzywne odpowiedzi na wszystkie dziesięć pytań wyjściowych. Kończą to podsumowanie następująco: „Jeśli kreatywność jako pole badań wyrosła z inteligencji, to mamy nadzieję, że nadal będzie obejmować różne inne konstrukty, takie jak mądrość, etyka i bezinteresowność. Takie tendencje będą miały wpływ nie tylko na nauki o kreatywności, ale także na świat" (s. 378).

Badacze twórczości otrzymali bardzo interesujący zbiór tekstów obrazujących stan i sposób myślenia o tym fenomenie czołowych badaczy amerykańskich. Nauki o kreatywności - kreatologia - znajdują się pod bardzo silnym wpływem uczonych 
znad Potomaku i Missisipi, którzy - to już definiuję jako ich istotny brak i błąd naukowy - raczej nie dostrzegają badań i pomysłów teoretycznych naukowców znad Wisły, Dunaju czy Renu. Ten amerykańskocentryczny punkt widzenia, oparty na bardzo silnym zapleczu finansowym i publikacyjnym (Impact Factor, a jakże!), jakimi dysponują uczeni z Harvardu czy Davis, nie pozwala im bezstronnie zauważyć, iż najlepszy w światowej kreatologii tekst o dziejach pojęcia twórczości wyszedł spod pióra polskiego filozofa - Władysława Tatarkiewicza, a jedną z najpłodniejszych systemowych teorii twórczości jest koncepcja transgresji twórczych Józefa Kozieleckiego. Dobrze, że Kazimierz Dąbrowski i jego teoria dezintegracji pozytywnej i wzmożonej pobudliwości psychicznej znalazła wdzięcznych kontynuatorów wśród amerykańskich i kanadyjskich psychologów twórczości. Prowadzi mnie to do wniosku, że recenzowana tu bardzo interesująca i cenna naukowo pozycja tylko zyskałaby na wartości, gdyby jej redaktorzy wyjrzeli poza brzegi Atlantyku. 